\title{
SHARIA COMPLIANCE RISK IN ISLAMIC BANK: DOES INDONESIA NEED TO ADOPT NEW SHARIA RISK RATING APPROACH?
}

\author{
Romi Adetio Setiawan \\ Western Sydney University, Australia \\ 169 Macquarie Street and 100 George Street, Parramatta NSW, 2150 di Parramatta CBD \\ Email: romi_adetio@yahoo.com
}

\begin{abstract}
The purpose of this study is to find the most relevant practice of supervision to manage Sharia Compliance Risk in Indonesian Islamic Bank based on the existing literature. The standard doctrinal approach is used to analyse, examine and evaluate the practice of Islamic banking supervision in Indonesia and Islamic banking in Malaysia for comparative purposes. The results revealed that the prior study on Sharia risk rating is applicable to manage Sharia Compliance Risk in Islamic Banks and their factors meet the Basel, AAOOIFI, and IFSB standards. However, there is no assessment made on evaluating the quality of supervision by Sharia Supervisory Board (SSB) members. Thus the study suggested the inclusion of additional factors on the performance of SSB. For Islamic Banking in Indonesia, this sharia risk rating approach can be combined with applicable internal and external risk rating techniques, to provide the promising quality of service and ensure that the offering of various products and services complies with Sharia rules and principles.
\end{abstract}

Keywords: Sharia Compliance Risk; Indonesia; Islamic Bank; Supervision

\begin{abstract}
Abstrak: Tujuan dari penelitian ini adalah untuk menemukan praktik pengawasan yang paling relevan untuk mengelola risiko kepatuhan syariah di Bank Umum Syariah Indonesia berdasarkan literatur yang ada. Pendekatan doktrinal standar digunakan untuk menganalisis, menguji, dan mengevaluasi praktik pengawasan perbankan syariah di Indonesia dan perbankan syariah di Malaysia, untuk tujuan perbandingan. Hasil penelitian menunjukkan bahwa penelitian sebelumnya tentang peringkat risiko syariah dapat diterapkan untuk mengelola risiko kepatuhan syariah di Bank Umum Syariah, dan faktor-faktornya memenuhi standar Basel, AAOOIFI, dan IFSB. Namun, belum ada penilaian kualitas pengawasan oleh anggota Dewan Pengawas Syariah (DPS). Dengan demikian, penelitian ini menyarankan dimasukkannya faktor tambahan pada kinerja DPS. Untuk Perbankan Syariah di Indonesia, pendekatan peringkat risiko syariah ini dapat digabungkan dengan teknik peringkat risiko internal dan eksternal yang berlaku, untuk memberikan kualitas layanan yang menjanjikan dan memastikan penawaran berbagai produk dan layanan sesuai dengan aturan dan prinsip Syariah.
\end{abstract}

Kata kunci: Risiko Kepatuhan Syariah; Indonesia: Bank Syariah; Pengawasan 


\section{Introduction}

The Banking Sharia Compliant is one of the main factors determining the choice of the bank by the consumers; from the Muslim's point of view, the decision to use the banking service is also reflecting their religious background. The Sharia compliance found to be the main reason for the customer to use the Islamic Banking service, followed by other factors such as insurance, empathy, reliability, and safety. ${ }^{1}$ Further, statistical evidence shows that religiosity holds a positive impact on customer's loyalty. ${ }^{2}$ Islam has strictly prohibited Riba(interest-rate) and other nonIslamic elements such as gharar (Uncertain transaction) and maysir (gambling). Islamic Banking as compared to others is upholding the ethical way of business, where it does not merely seek profits through their investment, but they also require dedicating on moral duty, by establishing justice and prohibiting exploitation, excessive risk or speculation in a business transaction, and taking into account a dimension of ethical nature, and social responsibility. ${ }^{3}$ This ethical way of thinking is derived from humankind's behaviour, many of which feel it is necessary to avoid the conduct and support that business with which cause the harmful to society such as tobacco, alcohol, gambling, and environmental degradation.

\footnotetext{
${ }^{1}$ Abdul Qawi Othman and Lynn Owen, "Adopting and Measuring Customer Service Quality (Sq) in Islamic Banks: A Case Study in Kuwait Finance House," International Journal of Islamic Financial Service 3, No. 1 (2001), p. 37.

2 Soegeng Wahyoedi, "The Effect of Religiosity, Service Quality, and Trust on Customer Loyalty in Islamic Banking in Bogor Indonesia," International Review of Management and Business Research 6, no. 1 (March 2017 2017), p. 25.

${ }^{3}$ Mohd Haniff Zainuldin, Tze Kiat Lui, and Kwang Jing Yii, "Principal-Agent Relationship Issues in Islamic Banks: A View of Islamic Ethical System," International Journal of Islamic and Middle Eastern Finance and Management 11, no. 2 (2018), p. 19.
}

Sharia means Islamic law, and Shariacompliant can be defined as an act or any activity that obeys the Islamic law, the term generally used by Islamic Banking and finance, to ensure that their business activities comply with Sharia as their services and products are in contrast from conventional banking. ${ }^{4}$ The authentication of products and services in Islamic Banking is emanated from credible Islamic Councils or Sharia Boards like the National Sharia Board of Indonesian Council of Ulama (Dewan Syariah Nasional Majelis Ulama Indonesia, DSN-MUI) in Indonesia, Sharia Advisory Council of Bank Negara Malaysia (SAC) in Malaysia, Sharia Financial Supervisory Board in Brunei, Sharia Supervisory Board (SSB), in the UK. These Sharia boards are made up of different backgrounds in Islamic jurisprudence and finance; their patronage towards the development of Islamic Banking is indispensable, and they have a passion for developing Islamic Banking within the sharia framework. ${ }^{5}$

As an Islamic Financial Institution, an Islamic bank expose to all risks which are born in a conventional bank, the bank has to take into account the risk and return of every banking transaction. However, the Islamic bank is also exposed to its unique risks e.g., Displaced Commercial Risk and Sharia Compliance Risk. The risks sphere in Islamic bank seems to be larger than the conventional banking, and the Sharia compliance risk is the most critical aspect for Islamic Banking to ensure that their customer is loyal and affect the image of customer perception toward Islamic Banking since the excellent

4 Syeda Fahmida Habib, Fundamentals of Islamic Finance and Banking (Newark, UNITED KINGDOM: John Wiley \& Sons, Incorporated, 2018), p. 41.

${ }^{5}$ IFSB, "Guiding Principles on Shari'ah Governace Systems for Institutions Offering Islamic Financial Services “(2009), p. 13. 
image of Islamic Banking depends upon the excellent reputation of Sharia compliance in banking operation which becomes the main competitive advantages of this bank. ${ }^{6}$

According to Rama the failure of the bank to consistently prove that its whole operations are Sharia compliance led to a bank customer switching behaviour from an Islamic bank to another bank. ${ }^{7}$ A Sharia index to measure the aspect of Sharia compliance risk is indeed necessary to disclose the bank credibility on Sharia values as there is an accusation in the society of Indonesia that Islamic banking businesses are operating in the same way as a conventional bank. ${ }^{8}$ It is credentialed for the Sharia Board members to have a best instrument that enable them to disclose to a public that the Islamic bank is well-supervised and operating the banking business Islamically, and that will strengthen the regulatory framework and governance practices for the Islamic financial industry.

\footnotetext{
${ }^{6}$ Mohammad Ziaul Hoq, Nigar Sulatana, and Muslim Amin, "The Effect of Trust, Customer Satisfaction and Image on Customers' Loyalty in Islamic Banking Sector," South Asian Journal of Management 17, no. 1 (2010); Muslim Amin and Zaidi Isa, "An Examination of the Relationship between Service Quality Perception and Customer Satisfaction: A Sem Approach Towards Malaysian Islamic Banking," International Journal of Islamic and Middle Eastern Finance and Management 1, no. 3 (2008/08/29 2008). https://doi.org/10.1108/17538390810901131; Khaled Hussainey and Sherif El-Halaby, "Determinants of Compliance with Aaoifi Standards by Islamic Banks," International Journal of Islamic and Middle Eastern Finance and Management 9, No. 1 (2016/04/18 2016).https://doi. org/10.1108/IMEFM-06-2015-0074.

${ }^{7}$ Ali Rama, "An Exploration of Customers' Switching Behavior in Islamic Banking Industry," Journal of Islamic Monetary Economics and Finance 2, No. 2 (2017), p. 26, https://doi.org/https://doi.org/10.21098/jimf.v2i2.653.

${ }^{8}$ Putri Reno and Rose Abdullah, "Risk Management Innovation of Islamic Financial Institutions," European Journal of Islamic Finance 4 (2016).https://doi.org/http:// dx.doi.org/10.13135/2421-2172/1649; Rifki Ismal, Islamic Banking in Indonesia: New Perspectives on Monetary and Financial Issues, Wiley Finance (Singapore: John Wiley \& Sons, 2013)..
}

\section{Research Objectives}

This study investigates the most relevant practice to manage the Sharia Compliance Risk in Islamic Bank in Indonesia. The Objective is three folds: First, to examine the appropriateness of Sharia Risk Rating Approach and its comparison to the Accounting and Auditing Organization for Islamic Financial Institutions(AAOOFI) standard, Islamic Financial Services Board(IFSB), and Basel. Second, to assess the practice of monitoring and supervision of Sharia Compliance Risk of Islamic Bank in Indonesia. Third, to investigate whether perceived Sharia Risk instrument and potential consumption barriers related to increment of consumer trust level. It furthermore sought to determine whether the use of Sharia Risk Rating Approach would be appropriate for Islamic Banking in Indonesia. The remaining sections would discuss about the program development for the role and important of Sharia Supervisory Board in increasing the Sharia Compliance on Islamic banking business transaction, based on the documentary review of relevant information. The research method and literature study based finding will be presented and discussed.

\section{Literature Review}

In order to sustain from Sharia compliance risk and increase the banking reputation, several authors stated that the Islamic banks need to have a robust model for managing this risk which generates maximum return and identifies the level of their tolerable risk. The dynamical model could be deployed to all Islamic financial institutions conducting Islamic banking business and adequate to work with the International standard of Basel. To assess the Sharia compliance risk, the Islamic Scholars have done a remarkable development by demanding the Islamic banks be rated in the aspect of sharia risk. By way of the Islamic risk 
rating approach, it would assist in measuring the indication of Sharia good performance (Sharia Compliance Risk) and the banking stability. ${ }^{9}$ The Islamic compliance reflects the banking credibility of managing its operation and a study found that the bank which is conducting Islamic compliance services and products have better profitability and stability in a Muslim majority region. ${ }^{10}$

Prominent research for measuring the sharia compliance risk is conducted by Ashraf and Lahsasna utilizes scorecard based modelling approach to assess the Sharia compliance risk of Islamic Bank in three countries (Saudi Arabia, Malaysia \& Pakistan), five areas are rated which are regulatory support, quality of Sharia supervision, business structure, product mix, and treatment of capital adequacy ratio. The scores are structured into four tiers, noncompliant, weak compliance, satisfactory compliance, and high-level sharia compliance. ${ }^{11}$ The system of calculation shows the area which part of the aspect needs to be improved to reduce the persistence of Sharia risk. This model can be applied by the Bank to adjust the capital requirement against Sharia risk under Basel III, and the regulator could use it widely to identify the level of Sharia compliance risk in Islamic banks. However, the study did not literally mention the appropriateness with the system of International Sharia risk control

9 Rafisah Mat Radzi and $\mathrm{Ku}$ Azam Tuan Lonik, "Islamic Banks' Risks: It's Rating Methodology and Shariah Assessment Solutions," Journal of Islamic Banking and Finance 4, no. 2 (December 2016 2016), p. 24, .https://doi.org/10.15640/jibf.v4n2a7..

${ }^{10}$ Irwan Trinugroho et al., "Does Religiosity Matter for Islamic Banks' Performance? Evidence from Indonesia "International Journal of Economics and Management 11, no. 2 (2017), p. 38.

11 Muhammad Adeel Ashraf and Ahcene Lahsasna, "Proposal for a New Sharīah Risk Rating Approach for Islamic Banks," ISRA International Journal of Islamic Finance 9, no. 1 (2017/07/10 2017), p. 11, https://doi. org/10.1108/IJIF-07-2017-008. standardization by the Accounting and Auditing Organization for Islamic Financial Institutions (AAOIFI) and guiding principles issued by the Islamic Financial Services Board (IFSB) and what compares this model to previous aspect.

Another study on the management of Sharia non-compliance risk is conducted by Shafii, Salleh and Shahwan they argue that the noncompliance risk could be managed through the sharia compliance audit programme that have an objective to report all transaction activities within the banking operations, and establish controls, policies and procedures to achieve the compliance with Sharia principles. ${ }^{12}$ The study, which is also comprehensive in identifying the issues of Sharia Compliance risk is done by Radzi and Lonik, the finding shows that the current credit rating system assed by credit rating agencies are inappropriate for Islamic Banks, since Islamic banks will not have the same level of sharia commitment a more comprehensive criterion to judge their stability is required to reflect their operational soundness. ${ }^{13}$

Grassa argues that the effectiveness of sharia supervision in Islamic bank is questioned, by examining two Sharia supervisory model in two leading Islamic Finance regions the Gulf Cooperation Council (GCC) countries and Southeast Asian countries, the result shows that the Sharia authority does not effectively supervise the Sharia products and Sharia ruling at the institutional level, the issues occurred due to the absence of a comprehensive regulatory framework governing Sharia boards and the ineffectiveness of instrument to control

${ }^{12}$ Zurina Shafii, Supiah Salleh, and Syahidawati $\mathrm{Hj}$ Shahwan, "Management of Shariah Non-Compliance Audit Risk in the Islamic Financial Institutions Via the Development of Shariah Compliance Audit Framework and Shariah Audit Programme," Kyoto Bulletin of Islamic Area Studies 3, no. 2 (March 2010 2010).

${ }^{13}$ Radzi and Lonik. 


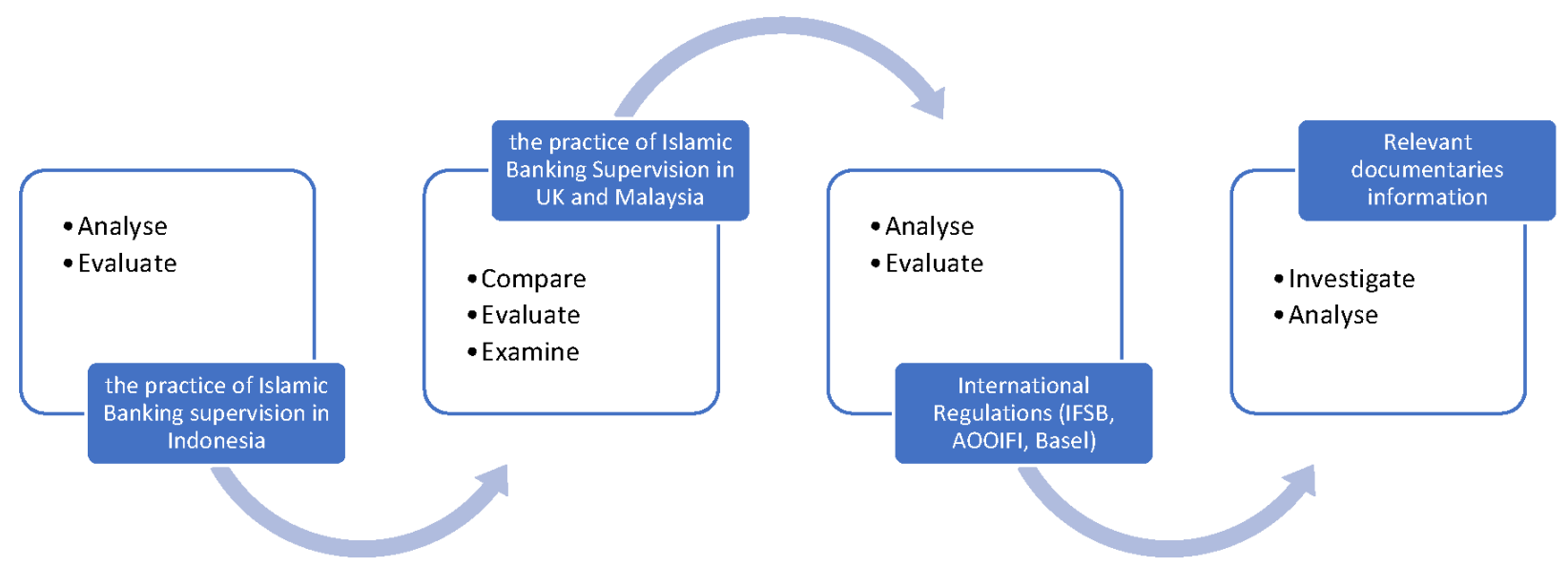

Table 1. Research Frameworks

the sharia compliance at Islamic Financial industry. ${ }^{14}$ Sharia authorities need to have more role in monitoring and supervising Islamic bank, and an improved system of sharia compliance supervision is indeed required to establish an effective Sharia governance system. This study thus fills in the previous study and suggest an instrument to identify the sharia risk compliance that do not contravene with International standardization.

Furthermore, Grassa, Kasim and Salman stated that the supervision and regulation of Islamic bank are varying across the countries, and the Sharia governance guidelines provided by international regulatory agencies such as AAOIFI, Bank Negara Malaysia(BNM) and IFSB are not comprehensive enough since these institutions have different objectives, the study argues that the guidelines should emphasis on the Sharia non-compliance function and have a unified standard that will enable industrial players, regulator, sharia advisors and investors refer to their regulatory framework easily. ${ }^{15}$

14 Rihab Grassa, "Shariah Supervisory System in Islamic Financial Institutions: New Issues and Challenges: A Comparative Analysis between Southeast Asia Models and Gcc Models," Humanomics 29, No. 4 (2013/10/28 2013), p. 38, https://doi.org/10.1108/H-01-2013-0001.

15 "Shariah Supervisory Systems in Islamic Finance Institutions across the Oic Member Countries," Journal of Financial Regulation and Compliance 23, No. 2 (2015), p. 53.

\section{Research Method}

This study will be based on literature-based research from the primarymaterialssuch as the governments regulations on Islamic banking, the guidelines of International banking standardization by International regulators (IFSB, AAOIFI and Basel), and from the relevant documentaries information regarding the measure of Sharia compliance risk in Islamic Bank.

A standard doctrinal approach is used in locating, analysing and evaluating relevant regulation relating to banking supervision of Islamic banking in Indonesia. For comparative purpose, it will also locate, examine and evaluate relevant regulation and supervision of Islamic banking in Malaysia. Regulations and standards from International bodies such as BASEL, IFSB and AAOIFI will be located, analysed and evaluated for the purpose of assessing the effectiveness and stability of Islamic Banking in Indonesia.

2015-06-25 2015); Nawal Kasim, Sheila Nu NuHtay, and Syedh Ahmad Salman, "Comparative Analysis on Aaoifi, Ifsb and Bnm Shari'ah Governance Guidelines “ International Journal of Business and Social Science 4, No. 15 (2013), p. 34. 


\section{Result and Analysis}

Sharia Compliance Risk in Islamic Banking

The risk in Islamic bank are more significant than those in Conventional Bank. As noted earlier, Islamic bank expose to all risk which are confronted in Conventional bank and it also exposed to its unique risk which is relevant to Islamic banks. Islamic Financial industry must comply with the Sharia principles, all transactions need to be approved by the Islamic Scholars and consistently following the Sharia law. Failure to do so, can lead to a fiduciary risk that arises from the failure of the bank to maintain their operational activities according to the regulation and applicable standard which cause a damage reputation and accountability of the bank, eventually it can cause a huge withdrawal from the customers that could result a liquidity risk, and subsequently customers switch their bank to other that cause a decline in profitability. ${ }^{16}$

Islamic banking relies on free interestbased transaction, the Islamic bank is strictly restricted to do a business which has an element of riba, all banking products from the offer to the implementation in the contracts in the practice should comply with Sharia. Sharia Compliance Risk is the nature risk that occurs in Islamic Bank, this risk is exposure to legal penalties and financial and material loss, it happens when the Bank fails to act in according with the Islamic law and regulations as prescribed. ${ }^{17}$ Thus, Islamic Bank should not be assessed in the same way as conventional banking, Sharia compliance

16 IFSB, "Shariah Non-Compliance Risk in the Banking Sector: Impact on Capital Adequacy Framework of Islamic Banks," in IFSB Working Paper Series (2016), p. 29.

17 "Shariah Non-Compliance Risk in the Banking Sector: Impact on Capital Adequacy Framework of Islamic Banks," p. 11. requirement should be taken into account in assessing the rating of Islamic banks. The Islamic Bank assessed in two aspects; Financial and Non-Financial. Financial consist of Capital Adequacy Ratio and the adherence of products (contract) to Sharia principle, and Non-Financial which are following the Sharia law, and jeopardize business reputation.

Currently, according IFSB 2005 guiding principle for managing Sharia Compliance Risk for Islamic Bank are referred to complement with the Basel Accord, and the risk management shall be undertaken in compliance with Sharia and within the legal framework of the jurisdictions. ${ }^{18}$ However, the Sharia Board has a responsibility to control the Sharia compliance risk and ensure the banking activities are conducted according to Islamic principles. ${ }^{19}$ Which means, the bank has to refer to Basel to meet their capital adequacy, liquidity and other operational purposes. However, no specific tool is established for Sharia Boards and Sharia regulator to manage the Sharia compliance risk.

The absence of instrument to index the sharia compliance risk and the inefficient regulation resulted the Sharia Boards fail to fully perform their function in the assessment and evaluation of Islamic Financial Industry. Based on survey in three countries (Malaysia, GCC countries and the UK), out of 80 Islamic Financial Industries surveyed, $42 \%$ in Malaysia, 23\% in GCC countries and none in the UK who evaluate the performance of Sharia Boards, It is also stated that only $10 \%$ of Sharia Boards are working full-time and caused most of the Sharia Board members do not evaluate, monitor and aware of the

18 "Guiding Principles of Risk Management for Institutions (Other Than Insurance Institutions) Offering Only Islamic Financial Services," in 1 (2005), p. 9.

19 "Ifsb-17 Core Principles for Islamic Finance Regulation (Banking Segment)," (2015), p. 7. 
application of the products by the Islamic Financial Industry. ${ }^{20}$

How is the practice of Sharia risk supervision in Indonesia and Malaysia?

There are certain similarities and dissimilarities in the practice of Islamic banking supervision in Indonesia and Malaysia, the Islamic Bank in both countries is supervised at two levels: Institutional level and National level, first is by the Sharia Supervisory Board in Indonesia and Sharia Advisory Council in Malaysia at the Institutional banking and Second is National Sharia Board in Indonesia and Sharia Committee in Malaysia at the national level. All of these boards are responsible to ensure all banking activities are following the Islamic principle. To support these Sharia Boards in fulfilling the task performance, the government in both countries provided regulations as per the need of the Sharia Boards, four areas are regulated: Criteria of Sharia Board qualifications, Duty and responsibility, the recognition of fatwa issuance, and independent body which is free from intervention. However, the regulation and supervision of Islamic bank still need further improvement, especially in the process of Sharia Compliance Risk which encounter in the field of recovery, mechanisms and dispute resolutions and the audit and review of Islamic compliance, and the disclosure of Islamic banking activities. ${ }^{21}$

In term of Sharia Compliance supervision, both countries are referring their standard to the AAOIFI Governance Standards for IFSB,

${ }^{20}$ Kabir M Hassan, Handbook of Empirical Research on Islam and Economic Life (Edward Elgar Publishing, Incorporated, 2016), p. 25.

${ }^{21}$ Agus Triyanta, "Implementasi Kepatuhan Syariah Dalam Perbankan Islam (Syariah) (Studi Perbandingan Antara Malaysia Dan Indonesia)," Ius Quia Iustum Law Journal of Islamic University of Indonesia 16 (2009), p. 62. provided that the Islamic bank at the same time also should follow the Basel Accord. The supervision of Islamic bank should be conducted from ex ante (from offering) and ex post (during the implementation). ${ }^{22}$ The Central Bank in both countries also enforce a sanction to those banks who breach the regulation and do not adhere to Islamic principle, in the form of cancellation of the operational permit, fine, or a notice. ${ }^{23}$

Table 2. Similarities and dissimilarities of Islamic banking supervision in Indonesia and Malaysia

Similarities
1. Appointment and Qualification for Sharia Board
2. Legal Entity
3. Level of supervision
4. Legal sanction

Dissimilarities

1. Task and duty

2. Concurrent positions for Sharia Boards

3. Review and audit

4. Effectiveness of regulation

In Indonesia the Sharia Supervisory Board members can concurrently have a position in other institutions (bank and non-bank) while in Malaysia the member only allowed for one institution which is the reason the supervision of Islamic bank in Malaysia found to be more effective, the SSB members in Malaysia are well equipped with Sharia transparency

${ }^{22}$ IFSB, "Guiding Principles on Corporate Governacne for Institutions Offering Only Islmaic Financial Services (Excluding Islamic Insurance (Takaful) Institutions and Islamic Mutual Funds)," (IFSB, 2006); AAOIFI, "Governance Standard for Islamic Financial Institutions," in 2, 2 (2002), p. 22.

${ }^{23}$ Kasim, NuHtay, and Salman; Act of the Republic of Indonesia, "Islamic Banking " in 21, ed. Republic of Indonesia (2008); Central Bank of Malaysia, "An Act to Provide for the Establishment, Administration, Powers and Duties of a Central Bank of Malaysia," in 519, ed. Central Bank of Malaysia (Malaysia: Central Bank of Malaysia 1958), p. 17. 
and accountability, Sharia audit, Sharia risk management and Sharia research. ${ }^{24}$ However, both countries are still lack of assessing the Sharia Boards, while in Indonesia there are no a single bank who evaluate their Sharia Supervisory boards. ${ }^{25}$

Another distinction also found in supervisory and advisory approach, the Sharia Supervisory Board in Indonesia act as a supervisory body, whereby it has a responsibility to ensure that the banking activities are complied with Sharia law and must give a report annually to Central Bank, and conversely the Central bank act as advisor and regulator to Islamic Bank. While in Malaysia is vice versa, the Sharia Advisory Board act as advisor to Islamic bank, the supervisory department of Central Bank is responsible to investigate and ensure that the Islamic bank is complied with Sharia principle. ${ }^{26}$ It can be concluded that, there are several factors which cause ineffectiveness of Islamic banking supervision by the Sharia Supervisory Board (SSB) in Indonesia: 1. The member of Sharia Supervisory Board consider this job not as the main occupation and do not fully focus on the profession, 2. The inefficient of regulations. 3. The ratio between Islamic bank and the number of SSB is not proportional 4. Most the SSB members' capacity are concentrated in Sharia law, none or a smaller amount have an expertise in banking operation, reporting, and auditing.

24 "An Act to Provide for the Establishment, Administration, Powers and Duties of a Central Bank of Malaysia."

${ }^{25}$ Naji Mansour Nomran, Razali Haron, and Rusni Hassan, "Shari'ah Supervisory Board Characteristics Effects on Islamic Banks' Performance: Evidence from Malaysia," International Journal of Bank Marketing 36, No. 2 (2018/04/03 2018).https://doi.org/10.1108/IJBM-122016-0197.

${ }^{26}$ Undang-Undang Republik Indonesia, "Perbankan Syariah " in 21, ed. Government of Indonesia (Indonesia 2008).
The guidelines of International agency in supervising Islamic Banks

In term of managing for Sharia Compliance Risk, there are three key components introduced by AAOIFI, 1. Establishment of Sharia Supervisory Board, 2. Sharia Review and 3. International Sharia Review. the Islamic bank is required to provide an Internal Sharia review who is proficient and have appropriate academic background for Sharia compliance management, to identify, measure, monitor, report and control the operational business of Islamic bank and ensure that their report is in conformity with AAOIFI and IFSB sharia standards and local regulatory authority. ${ }^{27}$ However, in practice the fact shows that there is no regularly and systematically investigation by the Sharia Boards from the document reported by the Sharia division, it is due to lack of investing activities, sincerity, poor attention in sharia audit, sharia research and lack of evaluating the Sharia board members and imprudent on following the guidelines. ${ }^{28}$

The Core Principles for Islamic Finance Regulation (CPIFR) for banking has been formally adopted by the IMF in 2018, these core principles were developed by the Islamic Financial Service Board (IFSB) with the collaboration of Basel Committee on Banking Supervision (BCBS). The CPIFR aimed at establishing the effective banking supervision that complement with Basel Core principles, by adding five new principles specifically for Islamic banking sector. ${ }^{29} 1$. Treatment of PSIA/

${ }^{27}$ AAOIFI, "Governance and Auditing Standards “ (AAOIFI, 2012), p. 12.

28 Samy Nathan Garas and Chris Pierce, "Shari'a Supervision of Islamic Financial Institutions," Journal of Financial Regulation and Compliance, Vol. 18, No. 4 (2010/11/16 2010), p. 35, https://doi.org/10.1108/ 13581981011093695 .

29 IMF, "The Core Principles for Islamic Finance Regulations and Assessment Methodology," ed. International 
IAHs, where the bank is fully responsible in managing the fund of their costumer and provide a return of profit earned. 2. Sharia Governance Framework, where the Sharia Board are fully responsible and authorised to assess Islamic bank to comply with Sharia rules at all time. 3. Equity Investment Risk, The Islamic Bank must manage their investment risk (Mudharabah and Musyarakah) in the banking book and ensure to have an enough capital when engaging with equity investment risk 4 . Rate of Return Risk (ROR), the supervisory authority determines that the procedure of ROR have been approved and reviewed, this risk arises from the possible impact on the net income and cash flow of Islamic Bank, arising from the fluctuation of the market, a benchmark of rates of return on assets and payable funding. 5. Islamic "windows' Operations, the supervisory authority control and provide a reasonable assurance that a. The Islamic windows transaction are complied with Sharia rules b. The banking book for Islamic and non-Islamic business are separated c. Follow the risk management policies and practices $\mathrm{d}$. Islamic windows provide a disclosure and transparency of their banking business.

From the above description, at least there are three areas still yet to be considered by the International guiding principles: 1 . There is no mechanism to control the treatment of Profit-Sharing Investment Accounts holders, which can lead to lack of disclosure and transparency of fund management by the bank. 2. Supervisory authority has not determined the availability of index that measure the level of Islamic bank in following the principle of Sharia rules, and review which areas do no satisfy the Sharia compliance and should

Monetary Fund (Washington, D.C.: International Monetary Fund 2018), p. 18. further be improved. 3. There is no guideline which assess the credibility of Sharia board members and evaluate their task performance in supervising Islamic bank. The absence of guiding principles on these aspects leads to poor attention of Sharia Compliance risk by the Sharia supervisory authority.

How is Islamic banking supervision in the view of Maqasidh Sharia?

Maqashid is derived from the Arabic word which means the propose/aims/principles, while Sharia is the Islamic law, Maqashid Sharia literally means the principles or guidelines which in accordance to Sharia law. According to Abu Zahra there are three principles of Maqasidh Sharia ${ }^{30}$ :

1. Tadzib al-fardh/educating individual, whereby each Muslim has to do a good deed, avoid any harmful conduct in the society, it is also aims at ensuring every acts are done in according to sharia principles.

2. Iqamah al-'adalah/establishing justice, it is a duty of every Muslim to be justice to all mankind, everyone has the same position in Islam and are submitted to their God, and all activities should be disclosed to build a trust and not to commit unjust acts against others.

3. Maslahah/Public interest, a proper Muslim should consider others in performing his action, which means it should be done for the sake of public interest.

30 Mustafa Omar Mohammed, Dzuljastri Abdul Razak, and Fauziah Md. Taib, "The Performance Measures of Islamic Banking Based on the Maqasid Framework," in IIUM International Accounting Conference (INTAC IV) (IIUM Malaysia2008); Muhammad Syafii Antonio, Yuliar D Sanrego, and Muhammad Taufiq, "An Analysis of Islamic Banking Performance: Maqashid Index Implementation in Indonesia and Jordania," Journal of Islamic Finance 1, No. 1 (2012), p. 52. 


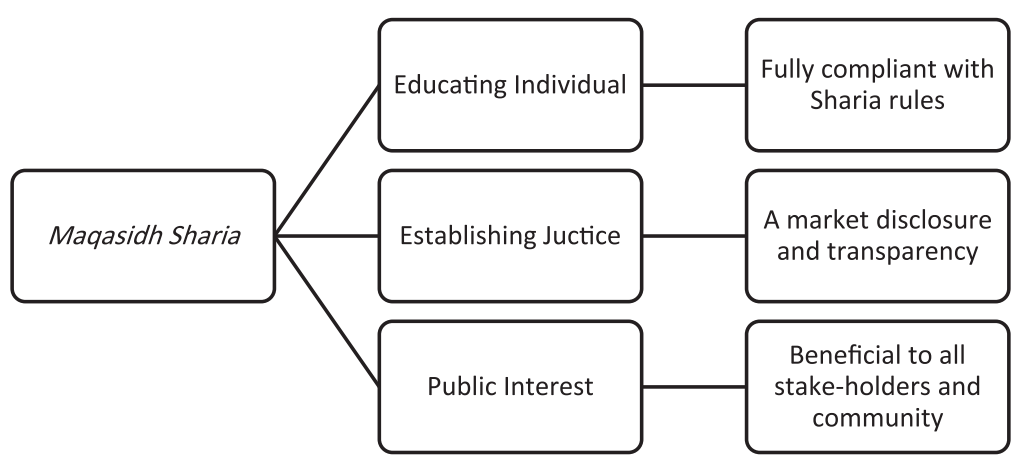

Tabel 3. the implementation of Maqasidb Sharia in supervising Islamic bank

From the above explanation, we can draw three main points for Islamic bank to act in according to maqashid sharia; 1. Tahzibul fardh, in which Islamic bank should comply with Sharia rules and principles. 2. Iqamah al'adalah, a market disclosure and transparency of the banking activities, 3 . Maslahah, ensuring the current Sharia practice for Islamic banking are of beneficial to all stake-holders and community.

These three areas, should be covered and added in the instrument of indexing the Islamic banking, and taken into account by the regulator to ensure that the banking business activities are complied with Maqasidh Sharia.

Should Indonesia Need to Adopt New Sharia Risk Rating Approach?

The Sharia compliance is a crucial part of the Islamic Financial industry, and it is often useful to measure this risk persistently in a majority Muslim country like Indonesia to convince customers to satisfy with sharia compliance of Islamic banks. The importance of Sharia risk rating for Islamic banks is that to measure the level of their Sharia commitment because all banks will not have the same level of commitment in Sharia compliance, and this is occurring in such a way based on the compliance process and the complexity of the bank. To provide pertinent analysis, whether or not Indonesia needs to adopt the Sharia risk rating approach, it is essential to reconsider the following questions:

- How is the adequate Sharia risk rating approach for Islamic banks?

- Is the Sharia risk rating approach's factors do not contravene with the International standard of Basel, IFSB, and AAOIFI?

- How does this Sharia risk rating approach affect the credibility of Islamic banking supervision?

The principal point of understanding how is the adequate sharia risk rating approach for Islamic bank is by analysing and comparing and evaluating the current fact methods and their coverage areas in rating calculation. The prominent and most recent research is conducted by Ashraf and Lahsasna using the Score Card System on 14 risk rating factors of overall Sharia counterparty financial risk, which are grouped into 5 major areas ${ }^{31}: 1$. Regulatory support, all Islamic banking contract transactions should be recognized by the law of the country. 2. Quality of Sharia Supervision, the Independency of Sharia Board in creating the periodically report 3. Business structure, legal incorporation, the fullfledged Islamic bank will be able to manage the implementation of Islamic laws in a better way than the Islamic unit branch of Conventional bank as the fund is segregated, 4. Product mix

${ }^{31}$ Ashraf, Muhammad Adeel, and Ahcene Lahsasna. "Proposal for a New Sharī'ah Risk Rating Approach for Islamic Banks." ISRA International Journal of Islamic Finance 9, No. 1 (2017/07/10 2017): p. 87-94. https:// doi.org/10.1108/IJIF-07-2017-008. 
(years in Islamic business, Implementation of AAOIFI and IFSB Standards, Charity fund, Width and depth of deposit products, Width of Asset Products, Debt-based products, structure of deposit) 5. Treatment of Capital Adequacy Ratio (See the table below).

Another essential rating methodology and Sharia assessment is led by Radzi and Lonik by comparing the implementation of credit rating by rating agencies: Standard \& Poor's, Moody's and Fitch (See the table below) in rating the conventional banks and Islamic banks and find that the rating agencies have not included the Sharia compliance criterion to judge Islamic bank stability. ${ }^{32}$ Standard \& Poor's, Moody's and Fitch used a quantitative and qualitative approach; quantitative elements of CAMELS are Capital Adequacy, Asset Quality, Management, Earnings, Liquidity, Sensitivity to Market Risk. In qualitative assessment covers: business model, management strategies and corporate policies, and business diversification and the history in handling the systemic risk.

Table 4. Conformity of sharia rating risk approach and International standard

\begin{tabular}{clc}
\hline No. & \multicolumn{1}{c}{$\begin{array}{c}\text { Ashraf and Lahsasna Sharia Risk } \\
\text { Rating Proposal }\end{array}$} & $\begin{array}{c}\text { Conformity } \\
\text { with IFSB, } \\
\text { AAOIFI } \\
\text { and Basel }\end{array}$ \\
\hline 1. & Regulatory support & $\sqrt{ }$ \\
\hline 2. & Quality of Sharia Supervision & $\sqrt{ }$ \\
\hline 3. & Business structure, legal incorporation & $\sqrt{ }$ \\
\hline 4. & $\begin{array}{l}\text { Product mix, (years in Islamic business, } \\
\text { Implementation of AAOIFI and IFSB }\end{array}$ & $\sqrt{ }$ \\
& $\begin{array}{l}\text { Standards, Charity fund, Width and } \\
\text { depth of deposit products, Width of } \\
\text { Asset Products, Debt-based products, } \\
\text { structure of deposit) }\end{array}$ & \\
\hline 5. & Treatment of Capital Adequacy Ratio & $\sqrt{ }$ \\
\hline
\end{tabular}

${ }^{32}$ Radzi, Rafisah Mat, and Ku Azam Tuan Lonik. "Islamic Banks' Risks: It's Rating Methodology and Shariah Assessment Solutions." Journal of Islamic Banking and Finance 4, no. 2 (December 2016 2016), p. 48-60. https://doi.org/10.15640/jibf.v4n2a7.

\begin{tabular}{lll}
\hline \multicolumn{3}{l}{ Standard \& Poor's, Moody's and Fitch } \\
\hline & Quantitative Approach & \\
\hline 1. & Capital Adequacy & $\sqrt{ }$ \\
\hline 2 & Asset Quality & $\sqrt{ }$ \\
\hline 3 & Management of Risk & $\sqrt{ }$ \\
\hline 4 & Capital Earnings & $\sqrt{ }$ \\
\hline 5 & Liquidity & $\sqrt{ }$ \\
\hline 6 & Sensitivity to Market Risk & $\sqrt{ }$ \\
\hline & Qualitative Approach & $\sqrt{ }$ \\
\hline 1 & Business model & $\sqrt{ }$ \\
\hline 2 & $\begin{array}{l}\text { Management strategies and corporate } \\
\text { policies }\end{array}$ & $\begin{array}{l}\text { Business diversification and the history } \\
\text { in handling the systemic risk }\end{array}$ \\
\hline
\end{tabular}

The above factors proved to have less effective in boosting the performance of Sharia Supervisory Board in handling the Islamic Bank; there is a need to harmonize Sharia risk rating and the performance of Sharia Board. As mentioned above, Sharia supervision is crucial for the Islamic finance industry, failure to do so can cause a destructive impact on this institution. The poor quality of supervision by the Sharia board members lead to inefficiency of evaluation, monitoring and supervision of the application of the banking business activities between the Islamic Financial Industry and stake-holders. Concerning this, it is suggested that there are three additional outcomes for Sharia risk rating approach assessment which are grouped into Performance of Sharia Supervisory Board:

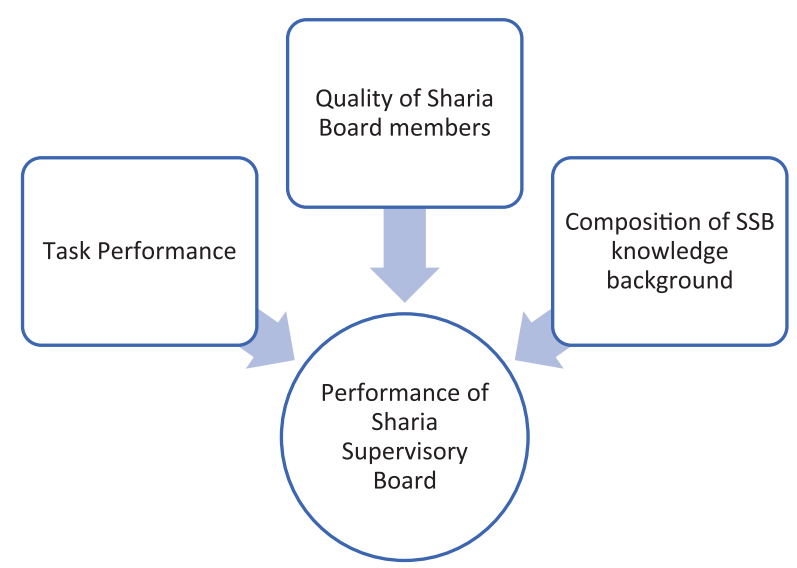

Table 5. additional factors for Sharia risk rating approach 
1. Task performance of Sharia Supervisory Board. Independency of the Sharia board members and the active or passive participation of the SSB in supervising the Islamic banks

2. Quality of Sharia Board Members, SSB with various banking experiences, skills, and expertise in fiqh lead to better supervision and product diversification and performance.

3. The composition of SSB knowledge background, qualification of the board members with a good level of education, plays a vital role in improving the company's competitiveness. The composition of sharia board in the background knowledge also determines the effectiveness of the supervision.

Since Islamic bank expose to a more risks than that of a conventional bank, due to its unique nature of banking as mentioned above, therefore, both Sharia risk rating approach and Conventional bank rating approach should be integrated. The focus of Sharia risk rating approach is to identify the level of sharia compliance quality of Islamic banks and to measure and control this risk by identifying which part of factors are vulnerable and need improvement.

The pertinent of Sharia risk rating approach incorporated with the International Regulatory Standards (Basel, IFSB, and AAOIFI) into the Islamic Bank system in Indonesia, will bring about better supervision of sharia compliance to the latter's overall banking structure.

\section{Conclusion and Recommendation}

This study is conducted using the standard doctrinal approach to analyse, examine and evaluate the current practice of the Sharia compliance supervision in two countries (Indonesia and Malaysia) and its appropriateness to the international regulatory body's principle guideline; it also locates the case at empirical investigation based on the literature study.
The results confirmed that the prior study on Sharia risk rating approach is an innovative instrument to manage the sharia risk compliance in Islamic bank and that their factors in determining the sharia compliance are in line with the International standard regulation by Basel, AAOOIFI and IFSB. However, the study also identified that there is lack of factor in term of evaluating the performance of Sharia Supervisory Board, as the Sharia board members is absolutely significant in the successful and effectivity of banking supervision and monitoring. Thus, transparency is indeed required in banking supervision as well as how the supervisor supervises the bank. For Indonesian Islamic Banking, the Sharia risk rating approach could be incorporated with their internal and external risk rating method to provide the promising quality of service and ensure the offer of a wide range of products and services are complying with Sharia rules and principles.

In addition to the effectiveness of regulation for Islamic banking in Indonesia, research from the literature review and the content analysis demonstrated that the clarity of policy on the composition between sharia board member's expertise in sharia law and banking, accounting, and reporting will lead to a high level of satisfaction in Banking supervision. Additionally, the performance quality of Sharia Supervisory Board would be based on how long the board members give their time and focus onto their duty and the extent to which this work is thought to be the main job or just a side job.

The limitation of this study was the difficulty in gathering more information regarding the practice of Sharia compliance supervision in the context of the Indonesian Islamic banking industry; this is due to a lack of substantive articles in the field. For further research, the researcher needs to increase the number of countries involved in the research study to 
achieve a better understanding of cross-countries analysis, and the result should be pertinent for the whole bank across the countries. In general, this study could further enrich the review on sharia compliance risk and be used as a consideration for banking practitioners, researchers, and regulators in determining the policy against the risk of Sharia compliance.

\section{References}

AAOIFI. "Governance and Auditing Standards": AAOIFI, 2012.

_. "Governance Standard for Islamic Financial Institutions." In 2, 2002.

Amin, Muslim, and Zaidi Isa. "An Examination of the Relationship between Service Quality Perception and Customer Satisfaction: A Sem Approach Towards Malaysian Islamic Banking." International JournalofIslamic and Middle Eastern Finance and Management 1, no. 3 (2008/08/29 2008): 191-209. https:// doi.org/10.1108/17538390810901131.

Antonio, Muhammad Syafii, Yuliar D Sanrego, and Muhammad Taufiq. "An Analysis of Islamic Banking Performance: Maqashid Index Implementation in Indonesia and Jordania." Journal of Islamic Finance 1, no. 1 (2012).

Ashraf, Muhammad Adeel, and Ahcene Lahsasna. "Proposal for a New Sharīah Risk Rating Approach for Islamic Banks." ISRA International Journal of Islamic Finance 9, no. 1 (2017/07/10 2017). https://doi. org/10.1108/IJIF-07-2017-008.

Grassa, Rihab. "Shariah Supervisory System in Islamic Financial Institutions: New Issues and Challenges: A Comparative Analysis between Southeast Asia Models and Gcc Models." Humanomics 29, no. 4 (2013/10/28 2013): 333-48. https://doi. org/10.1108/H-01-2013-0001.

Grassa, Rihab. "Shariah Supervisory Systems in Islamic Finance Institutions across the Oic Member Countries." [In English]. Journal of Financial Regulation and Compliance 23, no. 2 (2015-06-25 2015): 135-60.
Habib, Syeda Fahmida. Fundamentals of Islamic Finance and Banking. Newark, UNITED KINGDOM: John Wiley \& Sons, Incorporated, 2018.

Hassan, Kabir M. Handbook of Empirical Research on Islam and Economic Life. Edward Elgar Publishing, Incorporated, 2016.

Hoq, Mohammad Ziaul, Nigar Sulatana, and Muslim Amin. "The Effect of Trust, Customer Satisfaction and Image on Customers' Loyalty in Islamic Banking Sector." South Asian Journal of Management 17, no. 1 (2010): 70-93.

Hussainey, Khaled, and Sherif El-Halaby. "Determinants of Compliance with Aaoifi Standards by Islamic Banks." International Journal of Islamic and Middle Eastern Finance and Management 9, no. 1 (2016/04/18 2016): 143-68. https://doi.org/10.1108/ IMEFM-06-2015-0074.

IFSB. "Guiding Principles of Risk Management for Institutions (Other Than Insurance Institutions) Offering Only Islamic Financial Services." In 1, 31, 2005.

_. "Guiding Principles on Corporate Governacne for Institutions Offering Only Islmaic Financial Services (Excluding Islamic Insurance (Takaful) Institutions and Islamic Mutual Funds)." IFSB, 2006.

—. "Guiding Principles on Shari'ah Governace Systems for Institutions Offering Islamic Financial Services ", 2009.

-. "Ifsb-17 Core Principles for Islamic Finance Regulation (Banking Segment)." 2015.

- "Sharīah Non-Compliance Risk in the Banking Sector: Impact on Capital Adequacy Framework of Islamic Banks." In IFSB Working Paper Series, 2016.

IMF. "The Core Principles for Islamic Finance Regulations and Assessment Methodology." edited by International Monetary Fund, 39. Washington, D.C.: International Monetary Fund 2018.

Indonesia, Act of the Republic of. "Islamic Banking " In 21, edited by Republic of Indonesia, 2008. 
Indonesia, Undang-Undang Republik. "Perbankan Syariah" In 21, edited by Government of Indonesia. Indonesia 2008.

Ismal, Rifki. Islamic Banking in Indonesia: New Perspectives on Monetary and Financial Issues. Wiley Finance. Singapore: John Wiley \& Sons, 2013.

Kasim, Nawal, Sheila Nu NuHtay, and Syedh Ahmad Salman. "Comparative Analysis on Aaoifi, Ifsb and Bnm Shari'ah Governance Guidelines". International Journal of Business and Social Science 4, no. 15 (2013).

Malaysia, Central Bank of. "An Act to Provide for the Establishment, Administration, Powers and Duties of a Central Bank of Malaysia." In 519, edited by Central Bank of Malaysia. Malaysia: Central Bank of Malaysia 1958.

Mohammed, Mustafa Omar, Dzuljastri Abdul Razak, and Fauziah Md. Taib. "The Performance Measures of Islamic Banking Based on the Maqasid Framework." In IIUM International Accounting Conference (INTAC IV). IIUM Malaysia, 2008.

Nathan Garas, Samy, and Chris Pierce. "Shari'a Supervision of Islamic Financial Institutions." Journal of Financial Regulation and Compliance 18, no. 4 (2010/11/16 2010): 386-407. https://doi. org/10.1108/13581981011093695.

Nomran, Naji Mansour, Razali Haron, and Rusni Hassan. "Shari'ah Supervisory Board Characteristics Effects on Islamic Banks' Performance: Evidence from Malaysia." International Journal of Bank Marketing 36, no. 2 (2018/04/03 2018): 290-304. https:// doi.org/10.1108/IJBM-12-2016-0197.

Othman, Abdul Qawi, and Lynn Owen. "Adopting and Measuring Customer Service Quality (Sq) in Islamic Banks: A Case Study in Kuwait Finance House." International Journal of Islamic Financial Service 3, no. 1 (2001): 26.

Radzi, Rafisah Mat, and Ku Azam Tuan Lonik. "Islamic Banks' Risks: It's Rating Methodology and Shariah Assessment Solutions." Journal of Islamic Banking and
Finance 4, no. 2 (December 2016 2016). https://doi.org/10.15640/jibf.v4n2a7.

Rama, Ali. "An Exploration of Customers' Switching Behavior in Islamic Banking Industry." Journal of Islamic Monetary Economics and Finance 2, no. 2 (2017): 251-86. https://doi.org/https:// doi.org/10.21098/jimf.v2i2.653.

Reno, Putri, and Rose Abdullah. "Risk Management Innovation of Islamic Financial Institutions." European Journal of Islamic Finance 4 (2016): 10. https://doi.org/http:// dx.doi.org/10.13135/2421-2172/1649

Shafii, Zurina, Supiah Salleh, and Syahidawati Hj Shahwan. "Management of Shariah Non-Compliance Audit Risk in the Islamic Financial Institutions Via the Development of Shariah Compliance Audit Framework and Shariah Audit Programme." Kyoto Bulletin of Islamic Area Studies 3, no. 2 (March 2010 2010).

Trinugroho, Irwan, Tastaftiyan Risfandy, Mochammad Doddy Ariefianto, Agung Muhammad Prabowo, Heru Purnomo, and Yunastiti Purwaningsih. "Does Religiosity Matter for Islamic Banks' Performance? Evidence from Indonesia ". International Journal of Economics and Management 11, no. 2 (2017).

Triyanta, Agus. "Implementasi Kepatuhan Syariah Dalam Perbankan Islam (Syariah) (Studi Perbandingan Antara Malaysia Dan Indonesia)." Ius Quia Iustum Law Journal of Islamic University of Indonesia 16 (2009).

Wahyoedi, Soegeng. "The Effect of Religiosity, Service Quality, and Trust on Customer Loyalty in Islamic Banking in Bogor Indonesia." International Review of Management and Business Research 6, no. 1 (March 2017 2017).

Zainuldin, Mohd Haniff, Tze Kiat Lui, and Kwang Jing Yii. "Principal-Agent Relationship Issues in Islamic Banks: A View of Islamic Ethical System." International Journal of Islamic and Middle Eastern Finance and Management 11, no. 2 (2018). 